\title{
KLF3 Gene
}

National Cancer Institute

\section{Source}

National Cancer Institute. KLF3 Gene. NCI Thesaurus. Code C162392.

This gene plays a role in the regulation of erythroid-specific gene expression. 